\title{
Effects of rainfall variability and communal and semi-commercial grazing on land cover in southern African rangelands
}

\author{
Opha P. Dube ${ }^{1, *}$, Geoff Pickup ${ }^{2}$ \\ ${ }^{1}$ Department of Environmental Science, University of Botswana, Private Bag UB 00704, Botswana \\ ${ }^{2}$ CSIRO Land and Water, PO Box 1666, Canberra City ACT 2601, Australia
}

\begin{abstract}
Semi-arid ecosystems in southern Africa are experiencing change due to natural variability in rainfall and to changes in the type and intensity of land use. This paper applies grazing gradient techniques to vegetation cover dynamics in areas of communal and semi-commercial grazing in the Kalahari rangelands of Botswana to see whether human impact can be separated from that of climate variability. Landsat Thematic Mapper and Multispectral Scanner data were acquired for the Gumare and Hainaveld areas for a number of wet and dry seasons. Vegetation cover was mapped using the PD54 vegetation index. Gradients in both vegetation cover and vegetation response to rainfall were identified under communal use, suggesting both human impact and human-induced degradation. However, patterns were complex because of multiple focal points in the hinterland of larger settlements. Gradients in vegetation response were more effective than gradients in cover as identifiers of human impact in semi-commercial grazing areas. These gradients intensify in dry periods but vegetation partially recovers after good rains. Over time, however, the gradients are intensifying, suggesting that long-term grazing impact is occurring. As gradients intensify and degradation increases, vulnerability of grazing systems to rainfall variability and to drought is likely to intensify.
\end{abstract}

KEY WORDS: Rainfall variability $\cdot$ Grazing gradients $\cdot$ Remote sensing $\cdot$ Vegetation cover

\section{INTRODUCTION}

Reliable information about the effects of human activity on land surface processes in the semi-arid lands of southern Africa is lacking (Hulme et al. 2001, this issue). This is partly because semi-arid ecosystems show variability in response to both natural and anthropogenic disturbance (Westoby et al. 1989). This makes it difficult to interpret changes in vegetation cover and to separate human impact from natural processes such as response to wet periods, droughts and fire (Prince et al. 1990). There are also problems of data availability and interpretation. In many cases, a good time series of observations is required to detect change

*E-mail: dubeop@mopipi.ub.bw and this may be lacking. Procedures for interpreting short and often interrupted time series data are then needed (Pickup et al. 1998), but available techniques are often inadequate for detection of trends.

While semi-arid ecosystems of southern Africa do show variability, there is growing evidence of longterm change. In Zimbabwe, changes in floristic composition, decline in riverine forests, and change from woodlands to shrublands have occurred (Cambell \& Du Toit 1994). Changes in catchment runoff have also been noted (Lorup et al. 1998). In Botswana and South Africa, savanna landscapes show extensive bush encroachment and changes to herbage (van Vegten 1981, Bosch 1989, Hoffman \& Cowling 1990). Increases in human and domestic livestock populations have been identified as the main anthropogenic causes of change in Southern Africa (Dean et al. 1995). This has reduced 
wildlife habitat areas, increasing grazing pressure in some locations (Verlinden 1997).

Whether the changes to vegetation constitute land degradation or whether they are a response to landuse change that does not affect productivity remains a matter of controversy (Hoffman et al. 1995, Ward et al. 1998). Indeed, contrasting views on the extent and rate of land degradation are a feature of semi-arid lands and reflect limited understanding of the functioning of rangelands and their intrinsic relationship with communal grazing and associated land tenure systems (Behnke et al. 1993).

Issues of land degradation have been widely debated in all countries of southern Africa but particularly in Botswana, where beef production is the second most important economic activity after mining (de Queiroz 1993, White 1993). Cattle numbers have increased from 670000 in 1939 (Campbell 1978) to more than 3.5 million in 1978 (Ward 1978), although numbers fluctuate with drought. The increase came after the introduction of borehole technology in the 1950s, improvements in veterinary services, and the development of an export market servicing the European Community (Arntzen \& Veenendaal 1986). These changes were accompanied by introduction of land tenure systems supporting semi-commercial grazing operations focused on boreholes under the 1975 Tribal Grazing Land Policy (TGLP; Sandford 1980).

This study tries to discriminate between changes in vegetation arising from human land-use impacts and changes due to rainfall variability in areas of communal and semi-commercial grazing in Botswana. The approach is based on remotely sensed data and uses interpretation models derived from spatial patterns in land-use intensity. If human impacts can be separated, the results may be useful for rangeland monitoring on a large scale at relatively low cost. They might also provide input to regional climate change models and models of anthropogenic response to climate impact.

\section{BACKGROUND}

While the savanna landscapes of southern Africa experience substantial short- and medium-term rainfall variability, they are thought to be highly resilient (Cowling et al. 1997). Past land-use practices do not appear to have produced significant land degradation because population densities were low, settlements were often not permanent, and seasonal migration occurred (Dube 1992). This allowed time for ecosystem recovery between periods of localised but more intensive use.
More recently, political changes and development pressure, together with population increase, have led to land redistribution, a more sedentary population, increased land-use intensity and the introduction of commercial and semi-commercial grazing (Odada et al. 1996). The situation is made complex by the effects of wet periods and prolonged drought, both of which were experienced during the phase of major land-use change. Consequently, where degradation is suspected, it has proved difficult to measure its extent and rate of expansion.

Changes in vegetation and soil characteristics that may be associated with land degradation include: (1) a general increase in shrub density (a process known as bush encroachment); (2) a significant reduction in plant cover together with replacement of perennial palatable grasses by unpalatable species or by an ephemeral herbaceous layer, especially in the vicinity of boreholes and villages; and (3) change in soil surface characteristics, including nutrient status and water holding capacity. Changes to water resources have also occurred. These include a progressive drying up of surface water resources and a decline in underground aquifers (Dube \& Kwerepe 2000).

The countries of southern Africa are vulnerable to climate variability because of poverty and inequitable distribution of land resources, among other things (Downing 1996, Odada et al. 1996, Rowlands 1998). If there is widespread land degradation, the impact on communities may be exacerbated because some of the resilience provided by the natural landscape and by traditional land-use systems has been reduced (Magadza 1996, Nunes \& Auge' 1999). Interannual and interdecadal rainfall variability is high, although there has been no sustained trend during the 20th century until the last 2 decades. The 1970 s were a relatively wet period but annual average rainfall since then has been about $20 \%$ lower. Indeed, the rainfall year 1991-1992, linked to the El Niño-Southern Oscillation phenomenon, was the second driest year on record, and droughts since 1980 have been among the worst experienced (Watson et al. 1995, Hulme 1996).

Changes in vegetation cover driven by anthropogenic land-use change may have a feedback effect on climate (Walker 1994). Large-scale loss of land cover may affect surface albedo and evapotranspiration rates and may increase atmospheric aerosols through greater dust storm activity. The extent to which soil and natural vegetation provide carbon sinks may also be impacted (Scholes \& Parsons 1997). At present, there are many unknowns in this area. For example, shrub encroachment may provide a carbon store while the reduction in herbage cover associated with increased grazing pressure may offset that effect (Justice et al. 1993). 


\section{APPROACH}

Attempts to assess the extent of degradation in Botswana have been limited by a lack of data and absence of a methodology designed to cope with the characteristic spatial and temporal variations of nonequilibrium rangelands (see Pickup et al. 1994 for a general discussion of these issues). Ground-based surveys have only covered limited areas and faced sampling difficulties (Tolsma 1989, Perkins \& Thomas 1993, Moleele \& Perkins 1998). Satellite-based surveys have addressed the problems of areal coverage but initially used imagery for a single date, making it difficult to separate land degradation from short-term effects of drought (e.g. land degradation map of Botswana in Arntzen \& Veenendaal 1986).

The need to separate human-induced degradation from effects of variation in rainfall was recognised by Ringrose et al. (1990). Their approach involved regression of change over time in remotely sensed data against rainfall and stock numbers. However, interpretation proved difficult. Subsequent work has used spatial patterns in the landscape as a measure of landuse intensity, since this provides a means of separating out anthropogenic impacts (Perkins \& Thomas 1993, Ringrose et al. 1996, 1997, Moleele \& Perkins 1998, Dougill et al. 1999).

This paper applies grazing gradient methods to the situation in Botswana. These methods were developed for land degradation assessment in non-equilibrium rangelands under commercial grazing in arid Australia using remotely sensed data (Bastin et al. 1993, Pickup et al. 1994). However, they should apply more generally. Grazing gradient techniques use the patterns of grazing impact that develop outwards from boreholes or other foci of land-use concentration as spatial filters. Land degradation is defined as loss of ecosystem resilience and is expressed as a decline in the ability of vegetation cover to respond to rainfall. If this loss of ability varies systematically with distance from the focus, and natural sources of landscape variability are removed, it probably results from the effect of grazing. The methods use amount of vegetation cover rather than plant species composition, although both variables can be indicators of land degradation. This approach is taken because cover and cover change are much easier to measure from remotely sensed data. However, it is sometimes possible to infer changes in plant species composition due to grazing from the shape of grazing gradients (see below).

A reduction in the ability of vegetation to respond to rainfall does not necessarily mean the landscape is degraded. Grazed areas may take time to recover and smaller rainfall events do not always demonstrate the capacity of the landscape to respond fully. In these situations, changes in response to rainfall are often regarded as temporary for operational purposes. However, if the loss of capacity persists over major rainfall events, the impact is long term (Pickup et al. 1994, Ward et al. 1998). Where long-term impacts involve a loss of resilience, they may be classed as degradation, since plant productivity is reduced and vulnerability to drought increases (Pickup 1996).

While grazing gradients are expressed in terms of distance from a central focus, they are not derived by measuring line transects in the conventional manner. Instead, vegetation cover or cover change is measured at all locations at a specific distance from the focus point and then averaged. This removes much of the variation arising from local differences in landscape type, topography or vegetation type and provides a clearer picture of grazing impact.

Grazing gradients may be expressed in a number of ways depending on landscape response to disturbance (Pickup et al. 1994). In the simplest model, it is assumed that vegetation cover after good rainfall conditions reflects the ability of the system to respond to rainfall. However, in non-uniform landscapes, cover may vary because of systematic differences in landscape type with distance from the focal point. Also, the landscape may only recover fully from grazing after the largest rainfalls, so response to lesser rainfalls may not be a reliable measure of land condition. A second model uses vegetation response to rainfall as measured by the difference in cover between successive dry and wet periods. This removes some effects of landscape variability and often makes gradients much clearer.

Several types of gradient in vegetation cover occur out from boreholes (Pickup et al. 1994). Normal gradients show a general increase in cover with distance from the borehole under both wet and dry conditions, and are often associated with soil erosion gradients. Inverse gradients show a decrease in cover with distance under dry conditions but this effect often disappears after rain. This pattern may be associated with adverse changes in pasture species composition and bush encroachment. Composite gradients, which are a mixture of the normal and inverse gradients, are also common and often result from bush encroachment or an explosion of ephemeral herbage in the immediate area of the borehole.

Gradients in cover change between successive dry and wet periods are usually simpler. In most cases, more intense use close to the borehole reduces cover much more than further out. If the vegetation recovers, the increase in cover after a wet period should be greater near the borehole than further out. Where vegetation response is poor closer to the borehole and 
this situation persists through time, the landscape may have lost some of its capacity to respond to rainfall. Studies in Australia show that this situation occurs in areas of both erosion and bush encroachment (Pickup et al. 1994). The major limitation of the cover change approach is that a change in herbage composition from perennial to ephemeral plants may have occurred, and this will show up as a major response to rainfall, suggesting recovery from grazing.

The gradient approach should apply to semi-commercial grazing systems where the focal point is a borehole. However, it may require adaptation to the communal lands where land use is spatially complex with many focal points. These include water points, major villages, cattle posts and small semi-permanent settlements serving shifting cultivation. Gradients develop from harvesting of resources such as collection of fuelwood and material for house and fence construction (Kgathi et al. 1994). They are therefore influenced by the distance people can walk from settlements as well as by patterns of livestock grazing. We are there- fore dealing with utilisation gradients as well as gradients largely resulting from grazing and trampling by domestic animals, although the method of analysis remains the same.

\section{METHODS}

4.1. Selection of study areas. The work was carried out in the Ngamiland District, in the Kalahari Sandveld of north-west Botswana (Fig. 1). The Kalahari Sandveld is characterised by deep aeolian deposits, longitudinal dunes, pans and fossil valleys. The Okavango River enters the north-western part of Ngamiland from Angola and spreads over the Kalahari sands into a series of floodplains, channels and alluvial fans that form the Okavango Delta. The Delta provides surface water and replenishes aquifers but outflow on the western side has declined since the late 19th century (Shaw 1984, 1985). The sandy soils support woody savannah vegetation with a dense perennial but less
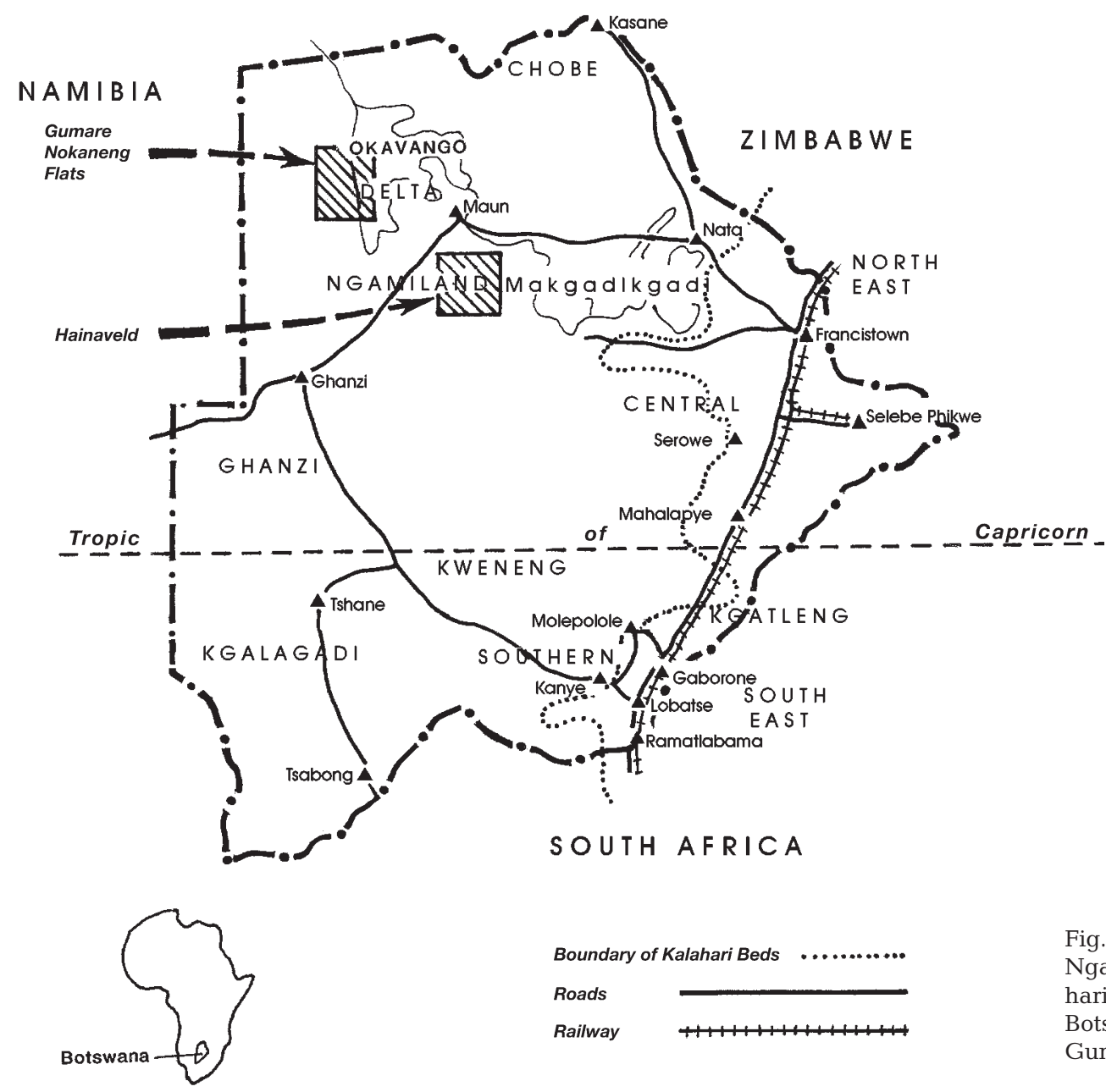

Boundary of Kalahari Beds

Roads

Railway
Fig. 1. Location map showing the Ngamiland District, in the Kalahari Sandveld of north-west Botswana. The 2 study sites, Gumare Nokaneng Flats and Hainafeld, are shaded 
nutritious grass layer. Dense vegetation occurs on the alluvial deposits. Mean annual rainfall ranges from 400 to $600 \mathrm{~mm}$ with a variability of 25 to $35 \%$ (Bhalotra 1987). Most of the rains fall in summer, from October to April. Veld fires are common during the dry period between June and September.

Ngamiland District comprises $18.6 \%$ of Botswana's area, has a population of over 80000 , and by 1996 carried 250000 cattle (Central Statistics Office 1992). However, $21.8 \%$ of the District is Wildlife Management Areas, National Parks, Forest and Game Reserves (White 1993).

Two sites were selected to represent the major land tenure systems practiced in the rangelands of southern Africa. These are communal lands in and around Gumare village on the western edge of the Okavango Delta; and semi-commercial TGLP leasehold ranches at Hainaveld, south of the Okavango Delta.

Gumare communal lands cover about 45000 ha, with $58 \%$ on the floodplain and the rest in an area of sandy soils. Subsistence cattle grazing is the main economic activity and internal migration is common. The Gumare floodplain had 34568 cattle in 1981 and this amounted to overstocking by 12800 livestock (Bendsen \& Gelmroth 1983). However, fluctuations in cattle numbers occur due to prolonged droughts, tsetse fly, foot and mouth disease and other epidemics. Smallscale crop production is the second largest occupation after cattle grazing. Two types of crop farming are practiced: floodplain farming which depends on Delta floods and dryland shifting cultivation in the sandy areas (Jones \& Rashem 1987). A series of droughts and reduction of Delta floods in recent years have constrained farming.

Hainaveld is predominantly Kalahari sands and, by 1995, carried over 13000 cattle, 6000 goats and other domestic livestock (Maun Veterinary Office 1995). Before 1975, the area had communal grazing but was later zoned into leasehold farms centred on boreholes, under the TGLP. The intention was to minimise grazing pressure in the communal areas and to control the spread of cattle diseases. Ranches of $8 \times 8 \mathrm{~km}$, each equipped with a borehole, were leased to pastoralists with relatively high livestock numbers (200 or more) for private use. TGLP ranches in the Hainaveld were planned to carry 300 animals, but many have exceeded this limit. The ranches are poorly managed, and there is free movement of livestock between ranches (Tsimako 1991).

4.2. Vegetation cover measurement by remote sensing. Gradients are measured from remotely sensed data transformed into a suitable vegetation index. This investigation applied PD54, a transform of the visible red and green bands of the Landsat Thematic Mapper (TM) and Multispectral Scanner (MSS) (Pickup et al.
1993). PD54 is a perpendicular difference image based on the tendency for rangeland soils and vegetation to plot within a parallelogram structure in the red-green spectral space. Soils form a band along one edge of this structure. Green and dry vegetation and plant litter all occur below the soil band and plot at a similar perpendicular distance from it, although green vegetation may be slightly further away. The index is calculated using the perpendicular distance index equations of Pickup \& Nelson (1984) and has had extensive use and testing in Australian rangelands and, more recently, in Botswana (Dube 2000a).

PD54 works best on red and yellow soils and has a range of 0 to 254 . Bare soils, representing $0 \%$ vegetation cover, usually plot between 40 and 90. Values above this range indicate increasing vegetation cover, with $100 \%$ cover generating values of 220 to 254 depending on greenness. The PD54 index is less affected by vegetation greenness than other commonly used vegetation indices. This is often an advantage when measuring cover in rangelands, because the green leaf component of trees and shrubs tends to produce greater values of most vegetation indices than a similar cover of dry herbage. Accuracy of cover measurement varies with the data source. Pickup et al. (1993) report correlation coefficients of about 0.9 between measured vegetation cover and PD54 values measured from airborne radiometer data. Correlations between PD54 values from Landsat TM data and cover values estimated from airborne videography were lower, with $r=0.70$ to 0.82 (Pickup et al. 2000). In both cases, these results are as good as, if not better than, those from other vegetation indices.

Patterns of change in vegetation cover were measured for wet and dry seasons between 1983 and 1996. Landsat MSS and TM data were used to calculate PD54. The multi-temporal satellite data were first standardised using relative calibration (Schott et al. 1988). The most recent PD54 data were validated using ground observations (Dube 2000b). Earlier PD54 values were validated from historical photographs (Dube 2000a). The range of values observed in Botswana is similar to that described in Australian rangelands over a range of seasonal conditions. Changes along gradients up to 70 PD54 values are common in both wet and dry seasons. Wet season-dry season shifts may be slightly greater.

4.3. Application of gradient method to study areas. Grazing gradient analyses were carried out on 10 leasehold farms on the Hainaveld. Rainfall data (Fig. 2) show that 1983 was a relatively poor wet season, 1989, 1991 and 1996 had good rains while 1995 represented drought conditions. Most farms were laid out in 1978 and were stocked from 1980 onwards, so the 1983 data might be taken to represent a baseline. 


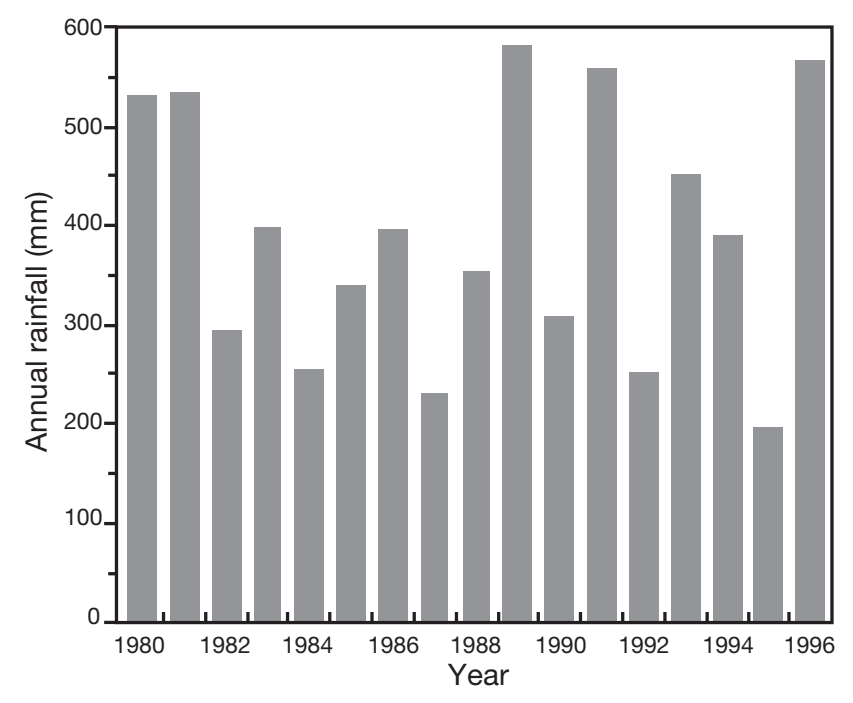

Fig. 2. Annual rainfall for Maun, 1980 to 1996 (Meteorological Services 1996)

Grazing gradient analysis is normally carried out on landscapes that have been stratified by land system or land unit. However, stratification has its limitations because it reduces the area available for analysis and, if areas become too small, the gradients reflect landscape variability within the land system. This variability may be quite high when compared with effects of grazing. In Hainaveld, the leasehold farms are small (6400 ha) in comparison with central Australian pastoral properties (with individual paddocks of 100 to $1000 \mathrm{~km}^{2}$ ), making it difficult to stratify the landscape. Instead, whole farms have been analysed using a drywet response approach. This filters out some of the landscape variability and gives a clearer indication of landscape response to grazing with increasing distance from water.

Where possible, we have used data for each wet season and its preceding dry season in the Hainaveld study. In one case, this was not feasible, so we approximated the change in cover using dry season data from the previous year. We have also used data from the 1991 wet season and 1993 dry season to show vegetation cover change under wet and dry conditions in the early 1990s. This illustrates the pattern of vegetation cover at increasing distance from boreholes and gives an indirect indication of the dry-wet response.

Gumare typifies the problems encountered when trying to conduct gradient analysis on landscapes in the communal land-use area. While most activity is centred on the main village of Gumare, there are several smaller semi-permanent settlements within a few kilometers of the main village (Fig. 3). These generate their own spatial patterns of land-use intensity that are superimposed on the pattern centred on the main village. Under these circumstances, the question is whether to construct spatial filters focused on all villages and to weight the influence of each one equally, or whether to centre activity on the main village from which most activity radiates. Here we analyse the landscape using the main village as a focus and carry out a secondary analysis for each of the smaller villages.

The Gumare data show the problems that occur when factors other than land-use and rainfall strongly influence change in vegetation cover (Fig. 3). While the village occurs in a sandy landscape, the eastern part of its sphere of influence includes channels and floodplains of the Okavango. Vegetation growth here is more dependent on the Delta floods than on local rainfall.

\section{RESULTS}

\subsection{Hainaveld}

Initial examination of PD54 values plotted against distance from water for each wet season and the preceding dry season on the Hainaveld generally shows more vegetation cover in the wet season. However, the analysis did not produce clear gradients. Instead, patterns were dominated by landscape variability. The PD54 graph for Ranch 7 in Fig. 4 shows an extreme example of this situation, with an apparent change in vegetation response to rainfall occurring about $5 \mathrm{~km}$ from water. This occurs because the ranch consists of a grassland area further from the borehole, which is preferred grazing country, and an area of woodland closer in, where the herbage response to rainfall would be much lower.

Rainfall response to distance from water, expressed as change in PD54, produces clearer results. Three examples covering Ranches 28, 38 and 19 are presented in Fig. 4.

Ranch 28 shows a typical combination of seasonal effects and a developing grazing gradient. In general, rainfall response improves as rainfall increases, irrespective of land condition. This means that the response to rainfall is limited in the baseline year but is substantial during the 1995-1996 wet season. A normal grazing gradient seems to have developed by 1983. This could reflect local landscape variability, particularly as the major increase in vegetation response with distance from water occurs beyond the $4 \mathrm{~km}$ point. Only a very small area of the ranch is situated beyond this perimeter, so the effect of local landscape variability relative to the impact of grazing on vegetation response could be high (Bastin et al. 1993). We do not believe this is the case, since the elevated response beyond $4 \mathrm{~km}$ does not persist through time. Such per- 


\section{Sandy zone}

$1989 w$

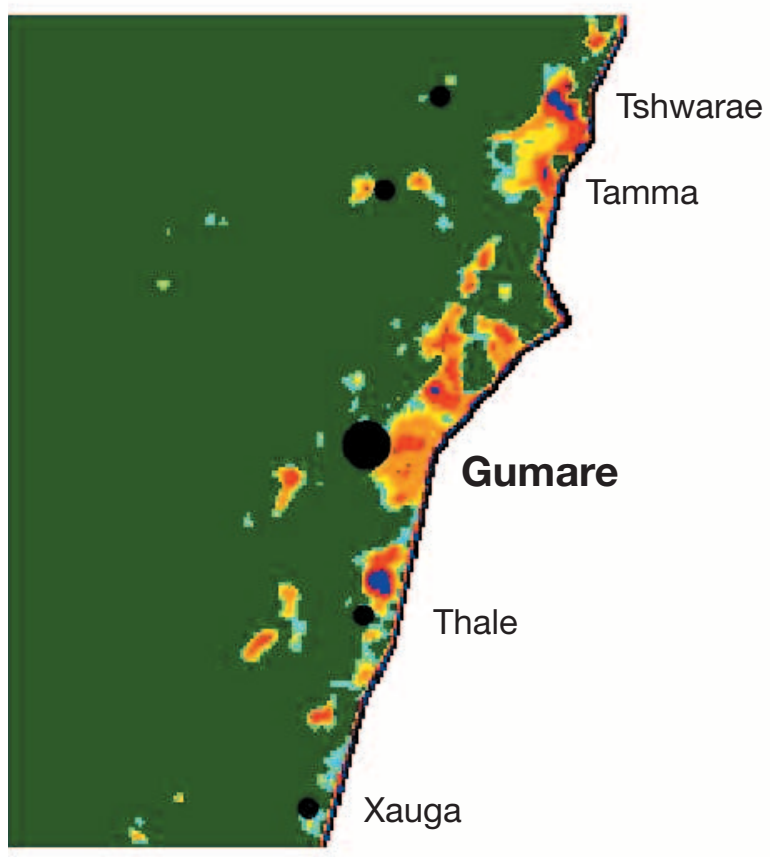

\section{$1989 d$}



Floodplain
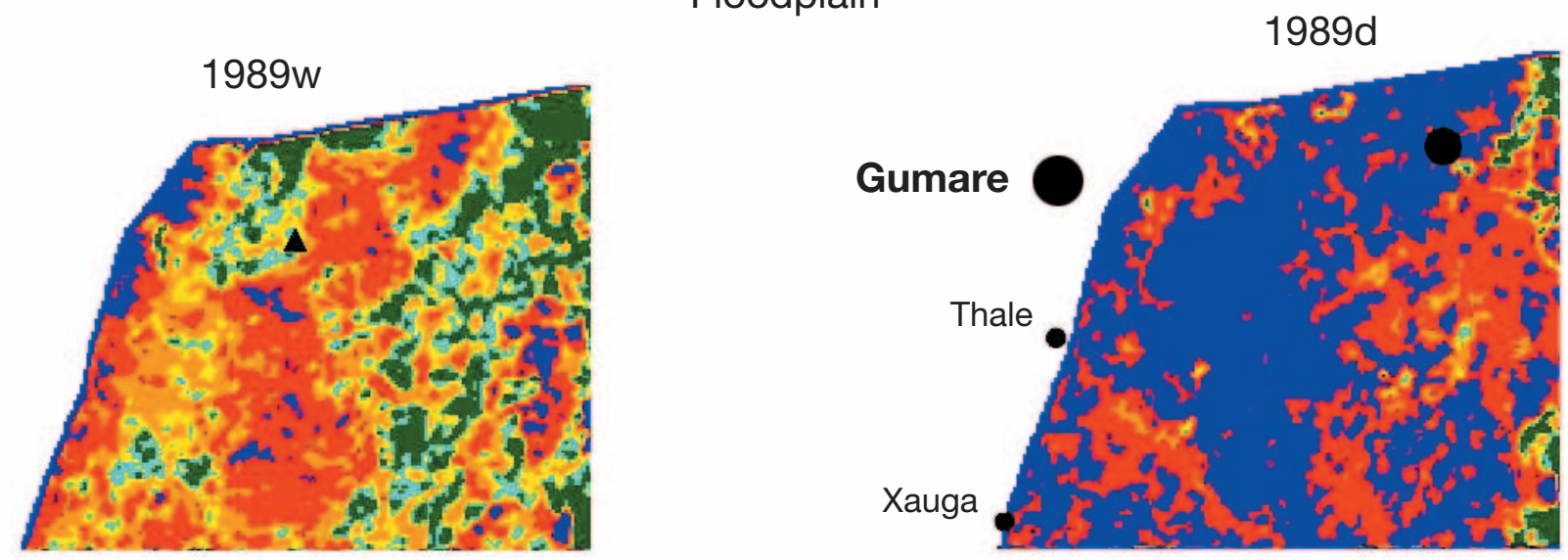

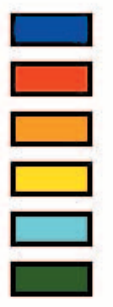

Bare

Sparse

Sparse-moderate

Moderate

Dense

Very dense

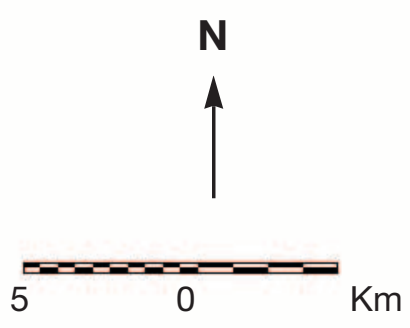

Fig. 3. PD54 images for the sandy zone and the floodplain areas around Gumare for the 1989 wet and dry seasons. Note the location of smaller settlements around the main centre 

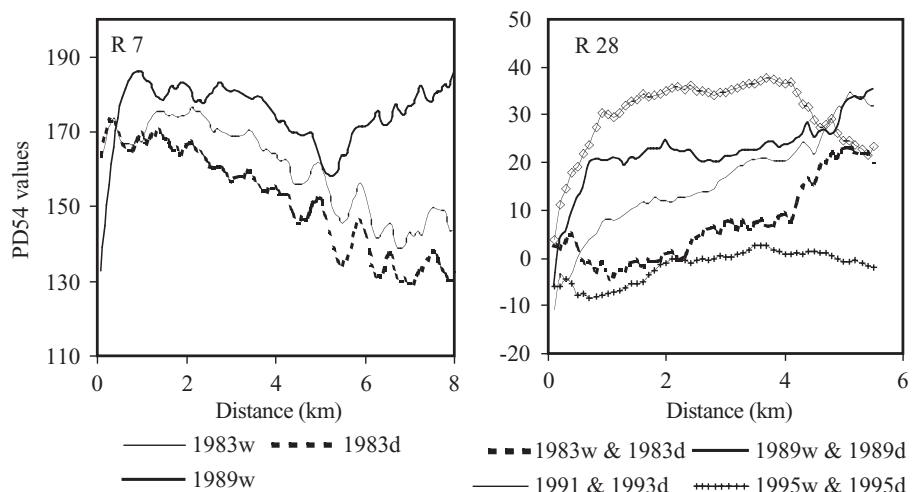

- - -1983w \& 1983d — 1989w \& 1989d 1991 \& 1993d

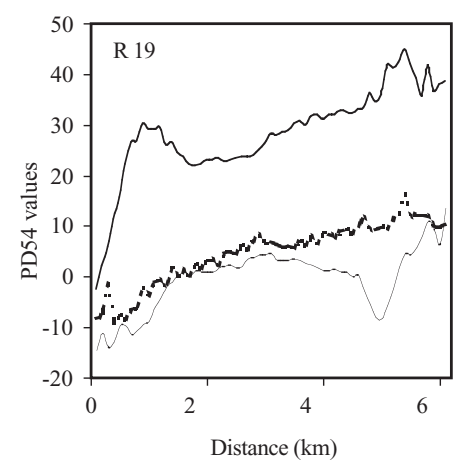

. - . - 1983w \& 1983d _ 1989w \& 1989d - 1991w \& 1993d

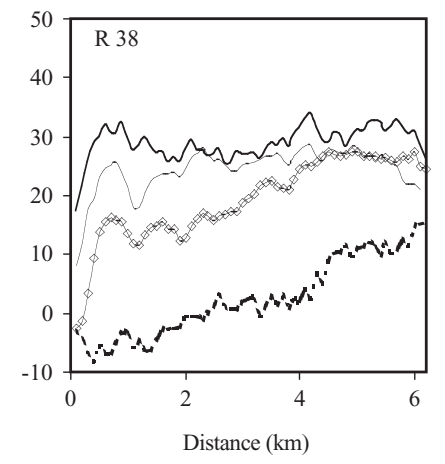

- - - 1983w \& 1983d - 1989w \& 1989d

— 1991w \& 1993d — 1996w \& 1995d

Fig. 4. Grazing gradients for selected Hainaveld ranches. The upper left-hand graph shows PD54 cover values for Ranch 7. The remaining graphs show dry-wet shifts in PD54 cover values for Ranches 19, 28 and 38

sistence would be expected if the pattern of response was due to a patch of ephemeral herbage with few trees, for example.

Rainfall was more substantial in 1989 than in 1983, but the utilisation zone within $0.6 \mathrm{~km}$ of the borehole on Ranch 28 shows a subdued vegetation response typical of land degradation. The utilisation zone is the area subjected to intensive pressure within the focal point from different land-use practices, including livestock activities. Beyond that point, vegetation response is fairly uniform, suggesting that the landscape recovers from grazing given sufficient rainfall. Changes in vegetation cover between 1991 and 1993 suggest that the grazing gradient is developing and the impact of cattle is beginning to extend out to the $4 \mathrm{~km}$ perimeter. The 1995 data show very limited response of vegetation to rainfall at all distances from the borehole. This reflects the low rainfall during a drought. However, we would still expect vegetation response to be greater with increasing distance from the borehole, whereas it is virtually the same beyond the $2 \mathrm{~km}$ perimeter. The absence of such a trend implies a grazing effect on vegetation response. The 1996 data show the extension of the

utilisation zone out as far as $1 \mathrm{~km}$ from the borehole and a lack of vegetation recovery even though the wet season rainfall was high. A weak grazing gradient also seems to be developing beyond this point.

A similar pattern emerges on Ranch 38. The weak grazing gradient is present in 1983, suggesting that the gradient on Ranch 28 in the same year is a grazing effect rather than the result of local variations in landscape type. In 1989 the utilisation zone is apparent but vegetation response to rainfall is high in all areas further out from the water. This suggests that most grazing effects were temporary at this stage. Between 1991 and 1993, the utilisation zone is still apparent but the impact of grazing is beginning to extend further out. By the 1995-1996 season, the impact of grazing is clearly extending beyond the utilisation zone, even though there were good rains.

Rainfall response patterns on Ranch 19 show that the trends on Ranches 28 and 38 may be general. The vegetation response in the 1983 wet season is lower close to the borehole in comparison to further out. The 1989 wet season response shows the development of a utilisation zone and what may be a grazing gradient extending further out. This gradient is apparent in the 1991-1993 data.

\subsection{Gumare}

Landsat MSS and TM data were acquired for 1983, 1989, 1994 and 1996 for the Gumare area and PD54 gradients for the sandy landscape are plotted in Fig. 5.
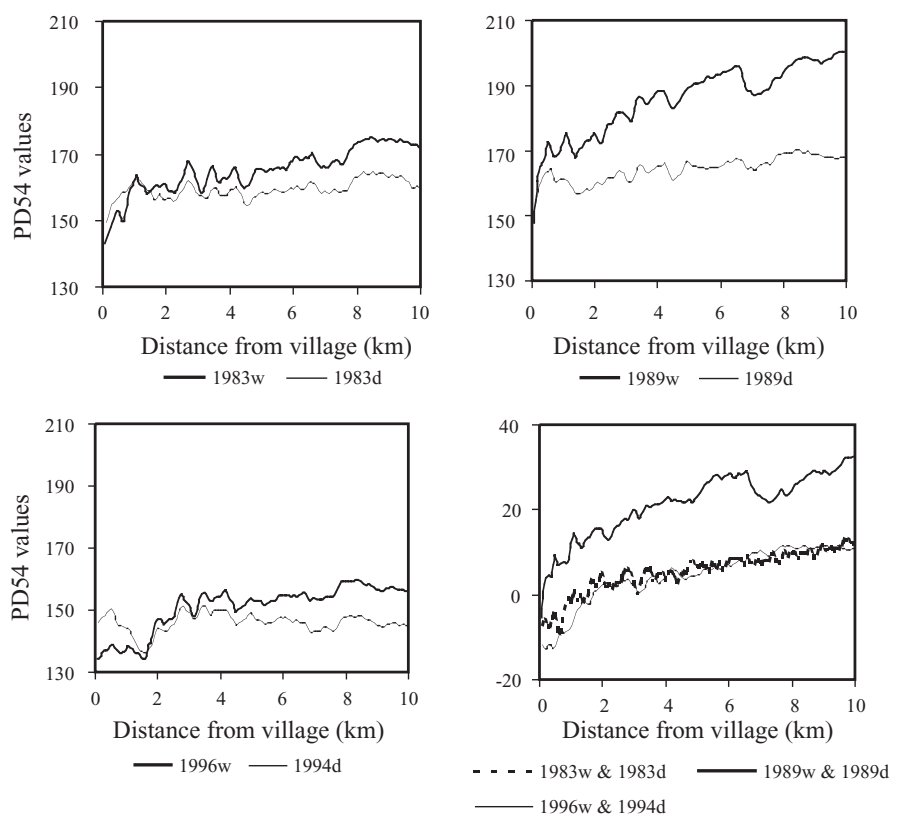

Fig. 5. PD54 cover values and cover difference gradients (dry-wet shifts in PD54 cover values) for the sandy area around Gumare 
Analysis of vegetation cover with distance from the main settlement in the sandy landscape shows a significant normal gradient after each wet season that is strongest after the good wet season of 1989. During the dry season, the gradient flattens, particularly during very dry times, and average cover shows only limited variation with distance from the village. This pattern suggests intensive use of whatever vegetation occurs and activities that radiate at least $10 \mathrm{~km}$ from the village. If this is the case, vegetation resources may be limited close to the village due to lack of capacity to respond to rainfall. People are therefore likely to be forced further out and may have to use plant material wherever it exists within walking distance.

The cover change data are shown in the lower right-hand graph of Fig. 5. In all 3 cases, the difference between wet season and dry season data increases with distance from the village. This indicates that the potential for vegetation recovery is substantially lower closer to the settlement. The gradient intensifies as conditions become wetter. Therefore, this impact is probably permanent and indicates a long-term reduction in landscape productivity in the areas of most intensive use.

The strong gradients in the sandy area in both vegetation cover and cover change that extend out from Gumare indicate that the influence of smaller settlements is not great enough to mask the general pattern in the sandy landscape. Also, cover response seems to be a stronger indicator of village impact than the simple cover values. We therefore examined the effect of 2 smaller settlements (Thale and Xauga) using cover change data (Fig. 6). In both cases, there is no sign of a consistent change in this variable with distance from the

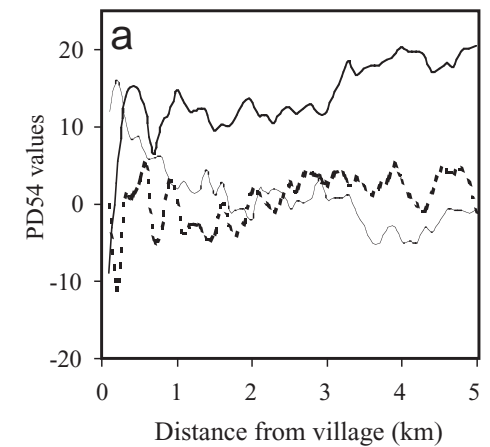

- - - - 1983w \& 1983d - 1989w \& 1989d 1996w \& 1994d

- - - 1983w \& 1983d - 1989w \& 1989d 1996w \& 1994d

Fig. 6. PD54 cover difference gradients (dry-wet shifts in PD54 cover values) around the small settlements of (a) Thale and (b) Xauga settlement over all rainfall events. The main effect seems to occur very close to the settlement and is expressed as substantial variation in cover response over a very short distance. This gives us some confidence in applying gradient analysis to larger settlements, even though there may be secondary land-use foci.

The floodplain landscape shows a different pattern of both vegetation cover and dry season-wet season cover change with distance from Gumare response (Fig. 7). For the first $4 \mathrm{~km}$, the landscape is strongly influenced by sandy islands and behaves in a similar way to the example discussed above. Beyond that point, the Okavango floodplain occurs, and the differences between wet and dry season cover are greater than in the sandy area. In 1983, wet and dry season cover are similar, suggesting either a poor rainfall season or a lack of flooding. In 1989 and 1996, cover levels are much greater, with a weak inverse gradient extending from about 4 to $10 \mathrm{~km}$, followed by a normal gradient between 10 and $15 \mathrm{~km}$. In the corresponding dry seasons, the inverse gradient intensifies out to about $7 \mathrm{~km}$, after which a normal gradient occurs. The cover change data for the floodplain show similar patterns to those observed in the cover data. 


\section{DISCUSSION}

\subsection{Hainaveld}

The Hainaveld vegetation response patterns show a strong relationship between rainfall amount and vegetation recovery from grazing. This indicates the need to use temporal data that include above- and belowaverage rainfall periods. Gradients observed during average and below average rainfall periods could be misinterpreted as effects of degradation. The 1983 patterns show that grazing effects were present and probably resulted from an influx of cattle immediately after the ranches were established. Where the borehole predated the ranches, for instance in Ranch 7, the effect is probably due to past communal based grazing activity.

The rainfall response patterns reveal the existence of a grazing gradient next to the boreholes. This zone extended outwards over time and was visible even during the very wet periods in 1989 and 1996. Grazing gradients develop because the borehole is the only watering point and surface water is lacking in these sandy environments (Dougill et al. 1999). All livestock have to return to the borehole each day because temperatures are high and the water is salty, both of which reduce the period between drinks. The expansion of this gradient shows the spread of potential long-term grazing impact over the ranches. This is likely to be exacerbated by the high stocking rates.

Well-developed gradients in cover and/or rainfall response may often be indirect indicators of bush encroachment and change in pasture species composition (Pickup et al. 1994). Consistently low response to rainfall when associated with high cover during dry periods may be an indicator of the spread of woody vegetation. Very high rainfall response associated with very low initial cover may also be an indication of changes in the herbaceous layer from perennial grasses to ephemerals. This often indicates a decline in range quality. For example, wet season ground transects on Ranches 38 and 19 in the 1996 wet season show that the proportion of ephemerals varies from 53 to $57 \%$ and from 69 to $75 \%$ respectively (Dube 2000a). This field survey also showed that, in the majority of Hainaveld ranches, the ephemeral hard stalked Dactyloctenium grass species that is palatable in the early part of the season was dominant. Schmidtia pappophoroides, which was reported to have been common when the ranches were first established in 1978, was rare in 1996. Stipagrostis uniplumis, which is more palatable to cattle than Dactyloctenium species, was more common closer to the perimeter fences than to the boreholes. A large proportion of ephemerals means that soil is not protected during droughts.
The Hainaveld data show that cover change is a more sensitive measure of grazing impact in gradient analysis than raw cover values. This occurs because the change due to grazing may involve bush encroachment which increases cover close to the waterpoint within the utilisation zone rather than reduces it. That increase prevails over the dry season when herbage cover is lost. Over time, an inverse gradient may develop in the raw PD54 values but this will take longer. Until then, use of raw cover data may not show the presence of a gradient, especially where ranches are relatively small and natural landscape variability is high.

A second issue in the Hainaveld data is the relatively large variation in vegetation response along gradients due to differences in rainfall between wet seasons. One approach to filtering out this effect and making changes in grazing impact over time clearer might be to standardise vegetation response by rainfall amount. Attempts to do this in Australia failed because of local rainfall variability and the lack of measurement stations. The same problems could be expected in the semi-arid lands of Botswana, where the rainfall stations are even less common. An alternative approach to filtering out rainfall variability and detecting underlying trends has been developed (Pickup et al. 1998), but we did not have enough Landsat data to apply it.

\subsection{Gumare}

The Gumare results show that gradients in the sandy area are similar to those observed in Hainaveld, where the Kalahari sands also occur and woody vegetation is common. Thus, although land tenure is not the same, the spatial impact of livestock rearing is similar. In Hainaveld, where cattle are free range, the borehole is the focal point. In communal areas, there is a need to protect crops from livestock and to protect livestock from wildlife. Cattle and goats are also required daily for milk. This means that they are penned at night in villages, creating a focus of activity other than stock watering points.

In Gumare, fresh water is available on the floodplain. Sandy areas within $5 \mathrm{~km}$ of the village are within the walking distance of the floodplain and hence receive grazing throughout the year. This zone is also used for dryland farming in years of good rainfall, such as 1989. This explains the normal gradients developed in this area. Sandy areas further out are grazed mostly in the wet season when surface water in pans is available.

The small cattlepost settlements in the sandy area, Thale and Xauga, show limited gradient development and relatively poor vegetation response to rainfall. Surrounding areas are very heavily used because of nearby surface water. The impact of trampling and grazing is sufficiently heavy to produce a uniform 
response that is low and remains largely unchanged with distance out to around $5 \mathrm{~km}$.

Patterns on the floodplain are more complex than in the sandy area. They reflect a reduction in flooding from the early 1980s, intensive land use due to availability of water and fertile soil, and the presence of the large secondary settlement of Tubu. Originally a cattle post, Tubu, has grown into a permanent village with 508 people in 1991 and over 600 livestock in 1995. The increase occurred mainly because of a reduction in tsetse fly after 1975 (Bowles 1986). Tubu is about $10 \mathrm{~km}$ from Gumare, and its impact probably explains the inverse gradient between 4 and $10 \mathrm{~km}$ and the normal gradient between 10 and $15 \mathrm{~km}$ on the Gumare plots (Fig. 7). Both these features are likely to be normal gradients centred on Tubu. The effect of Tubu was partly confirmed by field surveys in 1986 (Sekhwela \& Dube 1991) and 1996 (Dube 2000a). These show that the area was subject to wind erosion in dry months and sheet erosion in wet periods, which resulted in scalding and compaction.

The reduction in flooding, together with increasing utilisation, has had a significant effect that is not apparent from the gradient analysis. The floodplain zone between 4.5 and $7 \mathrm{~km}$ includes the floodplain of the Taoge River, the main channel on the western side of the Okavango Delta. Water from this channel ceased to reach Gumare in the 1980s. Vegetation subsequently changed from a riparian plant community to one dominated by ephemeral grasses. Increasing cattle grazing and a reduction in floodplain cultivation has left many areas devoid of plant cover for much of the year. The vegetation response curves show vegetation cover can be restored during periods of above average rainfall (500 to $600 \mathrm{~mm}$ ) but ephemerals dominate. The 1996 field survey showed that 76 to $86 \%$ of cover on the floodplain was ephemeral grass, consisting mainly of Urochloa trichopus (Dube 2000a). While this is a palatable species, it dries up and is blown away towards the end of the wet season. Because most of the fresh water is found on the floodplain, this area is used throughout the year. Loss of vegetation cover and extensive trampling means that the silty-clay soils experience severe wind erosion during the dry season and water erosion over wet periods (Snowy Mountains Engineering Corporation 1987, Sekhwela \& Dube 1991).

The developments in the Gumare floodplain are a warning of what might happen to large parts of the Okavango Delta (approximately $22000 \mathrm{~km}^{2}$ ) if flooding is permanently reduced and no plans are made to introduce appropriate land use. The potential for such a reduction in flow exists, from economic and climatedriven factors. Upstream water demands from $\mathrm{Na}$ mibia, and possibly from Angola when political stability is restored, are likely to increase in the 21st century.
There is pressure within Botswana to increase human use of the Okavango Delta water (Snowy Mountains Engineering Corporation 1987). Climate scenarios show that by the 2050s, rainfall in this area is likely to decline by $5 \%$ and temperature will increase by $1.5 \%$, leading to an increase of about $15 \%$ in potential evapotranspiration (Hulme 1996). Persistent drought in the last century contributed to the recession of floods in the Gumare area, although seismic activity (Reeves 1972) and land use had a role (Wilson 1973).

\subsection{Broader implications}

Human impact on climate results from cumulative local processes over time (Turner et al. 1995). The changes occurring around Gumare extend over a larger area of about $2000 \mathrm{~km}^{2}$ in the western part of the Okavango Delta and have wider consequences. These include loss of biological productivity, greater aerosol input to the atmosphere in the form of dust, increased albedo, changes in the soil carbon pool and release of other greenhouse gases into the atmosphere (Lal 1999, Scholes 1999). Case studies quantifying such processes in different parts of southern Africa would provide greater insight into the role of human-induced change in climate change.

There is a need to determine how increasing human impact affects vulnerability of societies to normal variations in rainfall. In Botswana, droughts are common and annual rainfall varies substantially from year to year, even in the wetter parts of the country (Fig. 8). The wetter Kalahari sands in the north receive rain from both Inter-Tropical Convergence Zone (ITCZ) and Atlantic Ocean air masses and have less than $30 \%$ variability (Bhalotra 1985). For example, Kasane has a mean annual rainfall of $647 \mathrm{~mm}$ and a coefficient of variation of $28.6 \%$ (Fig. 8). However, it is common for air masses from either or both sources not to reach northern Botswana, resulting in drought. Variability also increases as the climate becomes drier. Maritime air masses from the Indian Ocean bring rains to the south-eastern part of the country but this influence decreases westward. Thus, Serowe in central Botswana has a mean annual rainfall of $444 \mathrm{~mm}$ and a coefficient of variation of $36.3 \%$, while the south-western areas have an average annual rainfall of $250 \mathrm{~mm}$ and up to $80 \%$ variability. Current climate change scenarios show that aridity will increase in semi-arid lands of southern Africa centred over Botswana (Hulme et al. 2001).

Results from communal and semi-commercial grazing systems of Ngamiland in this study show that much of the available herbage biomass is used, except in years of higher rainfall (above $500 \mathrm{~mm}$ ). Only $30 \%$ of annual rainfalls at Maun in Ngamiland (Fig. 8) ex- 

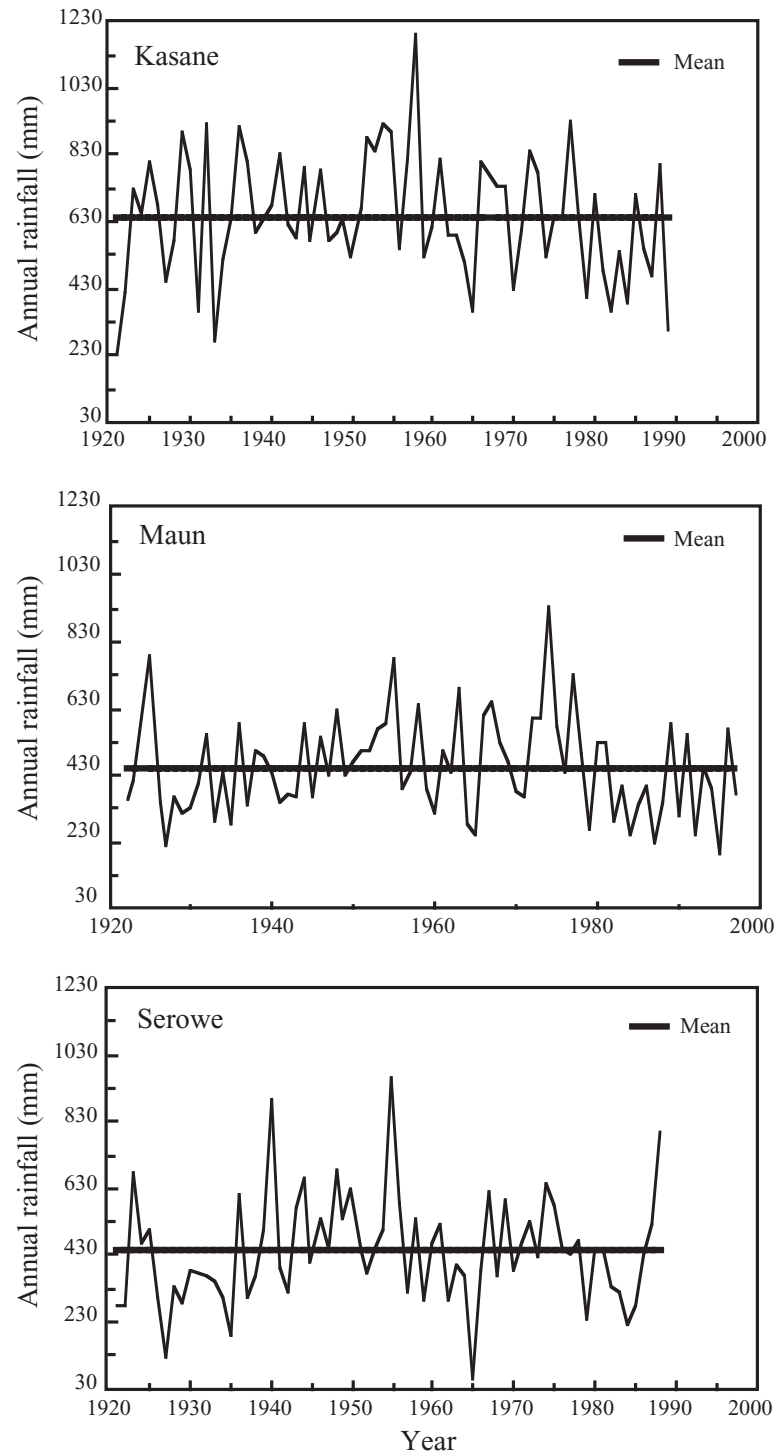

Fig. 8. Mean annual rainfall for selected Botswana locations (Meteorological Services 1996)

ceeded $500 \mathrm{~mm}$ between 1920 and 1996. This suggests that the area is vulnerable to land-use impacts for much of the time and potential for full recovery may be limited. At present, we do not have sufficient data to model the relative impacts of rainfall variability and land degradation on availability of biomass for grazing as the intensity of land use increases. However, studies from commercial grazing systems elsewhere show that, for a given set of rainfall conditions, situations when fodder is insufficient for livestock occur more frequently and last longer as land becomes more degraded (Pickup 1996). Furthermore, as stocking intensities increase and as more of the area of available land is used, drought impact becomes greater and potential for recovery of pastures during wetter periods is reduced. These conclusions are likely to apply to both semi- commercial and communal grazing systems of southern Africa. This underlines the need to retain land-use systems that have a high level of resilience. Indeed, there is a need to enhance that resilience as land use intensifies and new areas are opened to grazing.

\section{CONCLUSIONS}

This study has shown that patterns of vegetation response in the Hainaveld ranches were similar to those observed on large commercial properties in Central Australia (Bastin et al. 1993), despite the limited ranch size. This shows that the grazing gradient approach has potential for monitoring the semi-commercial ranching systems of southern Africa. Analysis by distance from focal point made it possible to assess the grazing effect and to distinguish it from rainfall variations. The vegetation response method was useful in reducing effects of natural landscape variation. When used as a monitoring tool, at selected intervals, the gradient methods will make it possible to identify and measure the progress of grazing impacts on the landscape. This approach has the potential to standardise assessment of land degradation due to land-use impact, especially when combined with intermittent ground observations. These observations add information on species and structural change in plant cover and on soil status at selected sites.

The patterns around Gumare show that gradients develop under communal land use and may be monitored using remote sensing techniques such as gradient analysis. The main problem is to identify appropriate focal points on which to base the analysis. Where a sedentary pattern of land use is developing, the main settlements seem a good choice but their influence may overlap and patterns may be quite complex.

Limited ability to detect a shift from perennial to ephemeral herbage restricts the usefulness of the vegetation cover and simple vegetation cover response models used here. More complex models of vegetation response or the use of variance gradients (Pickup et al. 1994, Bastin et al. 1996) may solve this problem. Gradient analysis techniques were not designed to monitor changes in vegetation cover arising from reduced flooding. However, they could be used to track subsequent changes due to land use.

Patterns of change over time show that both land-use and rainfall variability influence vegetation cover. Models of response and feedback to climate change from land cover variability need to reflect both processes. While rainfall variability produces large changes in cover over time, the impact of land use is significant and is probably growing. Recently developed trend analysis and impact evaluation procedures could pro- 
vide more definitive information in this area (e.g. Pickup 1996, Pickup et al. 1998) as high-resolution remotely sensed data accumulate. The relative impacts of rainfall variability and land use lead us to ask whether greater intensity of land use may be of equal or greater importance than that of climate change. The question is worthy of further investigation.

Acknowledgements. This study was carried out with financial assistance from the Australian Centre for International Agricultural Research (ACIAR), the European Union, and the University of Botswana. IGBP-DIS provided some of the images through START. The Ministry of Agriculture, Range Ecology Division in Botswana recommended this study and provided fieldwork support; we are particularly grateful to Raymond Kwerepe for this initiative. Staff at the CSIRO Centre for Arid Zone Research (particularly Gary Bastin and Vanessa Chewings) played a major role in the design and analytical framework of this study. Geoff McDonald, University of Queensland, and Mark Stafford Smith, CSIRO, supervised the PhD work of O.P.D

\section{LITERATURE CITED}

Arntzen JW, Veenendaal EM (1986) A profile of environment and development in Botswana. IES Free University, Amsterdam, and NIR, University of Botswana, Gaborone

Bastin GN, Pickup G, Chewings VH, Pearce G (1993) Land degradation assessment in central Australia using a grazing gradient method. Rangeland J 15:190-216

Bastin GN, Pickup G, Stanes A (1996) Estimating landscape resilience from satellite data and its application to pastoral land management. Rangeland J 18:118-135

Behnke JR, Scoones I, Kerven C (1993) Range ecology at disequilibrium. New models of natural variability and pastoral adaptation in African savannas. Overseas Development Institute, International Institute for Environment and Development, Commonwealth Secretariat, London

Bendsen H, Gelmroth H (1983) Land use planning in the Ngamiland Communal First Development Area. North West District Council, Tawana Land Board, Ministry of local Government and Lands, Maun

Bhalotra YPR (1985) Rainfall maps of Botswana. Department of Meteorological Services, Ministry of Works and Communications, Gaborone

Bhalotra YPR (1987) The drought of 1981-87 in Botswana. Department of Meteorological Services, Ministry of Works and Communications, Gaborone

Bosch OJ (1989) Degradation of semi-arid grasslands of southern Africa. J Arid Environ 16:165-175

Bowles J (1986) The aims and consequences of tsetse control in Botswana. Proc 3rd conservation seminar for district authorities. Department of Wildlife and National Parks. Ministry of Commerce and Industry, Gaborone, p 76-90

Cambell BM, Du Toit RF (1994) Vegetation patterns and the influence of small-scale farmers in a semi-arid savanna area in Zimbabwe. Kirkia 15:10-32

Campbell AC (1978) The 1960s' drought in Botswana. Botswana Society, Gaborone

Central Statistics Office (1992) Botswana in figures. Botswana Government Printing and Publishing Services, Gaborone

Cowling RM, Richardson DM, Pierce SM (eds) (1997) Vegetation of Southern Africa. Cambridge University Press, Cambridge
Dean WRJ, Hoffman MT, Meadows M, Milton SJ (1995) Desertification in the semi-arid Karoo South Africa: review and assessment. J Arid Environ 30:247-264

de Queiroz JS (1993) Range degradation in Botswana: myth or reality? Overseas Development Institute, London

Dougill AJ, Thomas DSG, Heathwaite AL (1999) Environmental change in the Kalahari: integrated land degradation studies for nonequilibrium dryland environments. Ann Assoc Am Geogr 89:420-442

Downing TE (ed) (1996) Climate change and world food security. Proceedings of the NATO Advanced Research Workshop, Oxford, 1993. NATO ASI Series 1, Vol 37. Springer, Berlin

Dube OP (1992) Notes on ecology and society in southern Africa. In: Irele A (ed) African education and identity. Proc 5th Session of the International Congress of African Studies, Ibadan. Hans Zell Publishers, London, p 357-368

Dube OP (2000a) Monitoring human induced change in communal and leasehold rangelands of Botswana. PhD thesis, University of Queensland

Dube OP (2000b) Standardising and validating high spatial resolution satellite data in the Kalahari rangelands of Africa. Proc 28th Int Symp Rem Sens and 3rd Symp Afr Assoc Rem Sens Environ, 27-31 March 2000. Information for sustainable development. CD ROM, CSIR Satellite Applications Centre, Cape Town

Dube OP, Kwerepe RM (2000) Human induced change in the Kgalagadi sands: beyond the year 2000. In: Ringrose S, Chanda R (eds) Towards sustainable management in the Kalahari region - some essential background and critical issues. Proc Botswana Global Change CommitteeSTART Kalahari Transect Meeting, Gaborone, 1998. Directorate of Research and Development, University of Botswana, Gaborone, p 244-258

Hoffman MT, Cowling RM (1990) Vegetation change in semiarid eastern Karoo over the last two hundred years: an expanding Karoo-fact or fiction? S Afr J Sci 86:286-294

Hoffman MT, Bond WJ, Stock WD (1995) Desertification of the eastern Karoo, South Africa: conflicting palaeo-ecological historical and soil isotopic evidence. J Arid Environ $37: 159-77$

Hulme M (1996) Climate change and Southern Africa: an exploration of some potential impacts and implications for the SADC region. Report Commissioned by WWF. Climate Research Unit, University of East Anglia, Norwich

Hulme M, Dougherty R, Ngara T, New M, Lister D (2001) African climate change: 1900-2100. In: Desanker P (ed) Africa and global climate change. CR SPECIAL 8. Clim Res 17:145-168

Jones RB, Rashem K (1987) Findings and results of research into molapo farming systems of western Ngamiland, Botswana. Agricultural Development Ngamiland. Department of Agricultural Research, Ministry of Agriculture, Gaborone

Justice C, Scholes B, Frost P (1993) African Savannas and the Global Atmosphere Research Agenda. Report of a Joint IGBP/START/IGAC/GCTE/GAIM/DIS Workshop on African Savannas, Land-use and global change: interactions of climate, productivity and emissions. IGBP Report 31

Kgathi DL, Sekhwela MBM, Tietema T, Mpotokwane MA (1994) Biomass in Botswana. In: Hall DO, Mao YS (eds) Biomass energy and coal in Africa. African Energy Policy Research Network (AFREPREN). ZED Books Ltd, London, p $17-67$

Lal R (1999) World soils and the greenhouse effect. Global Change Newsl 37:4-5

Lorup JK, Refsgaard CJ, Mazvimavi D (1998) Assessing the 
effect of land use change on the catchment runoff by combined use of statistical tests and hydrological modeling: case studies from Zimbabwe. J Hydrol 205:147-163

Magadza C (1996) Climate change: some likely multiple impacts in Southern Africa. In: Downing TE (ed) Climate change and world food security. Proc NATO Advanced Research Workshop, Oxford, 1993 NATO ASI Series 1, Vol 37. Springer, Berlin, p 449-483

Maun Veterinary Office (1995) Cattle-crash figures for Gumare and Hainaveld. Ministry of Agriculture, Gaborone

Meteorological Services (1996) Rainfall data. Ministry of Works and Communications, Gaborone

Moleele NM, Perkins JS (1998) Encroaching woody plant species and boreholes: is cattle density the main driving factor in the Olifants Drift communal grazing lands, southeastern Botswana? J Arid Environ 40:245-253

Nunes C, Auge' JI (eds) (1999) Landuse and landcover (LUCC) implementation strategy. IGBP Report 48, IHDP Report 10, Stockholm

Odada E, Totolo O, Stafford Smith M, Ingram J (1996) Global change and subsistence rangelands in Southern Africa: the impacts of climatic variability and resources. Access on rural livelihoods. GCTE Working Document 20. GCTE Core Project Office, Canberra

Perkins JS, Thomas DSG (1993) Environmental responses and sensitivity to permanent cattle ranching, semi-arid western central Botswana. In: Thomas DSG, Allison RJ (eds) Landscape sensitivity. John Wiley \& Sons, New York, p 273-286

Pickup G (1996) Estimating the effects of land degradation and rainfall variation on productivity in rangelands, an approach using remote sensing and models of grazing and herbage dynamics. J Appl Ecol 33:819-832

Pickup G, Nelson DJ (1984) Use of Landsat radiance parameters to distinguish soil erosion, stability and deposition in central Australia. Remote Sens Environ 16:195-209

Pickup G, Chewings VH, Nelson DJ (1993) Estimating changes in vegetation cover over time in arid areas from remotely sensed data. Remote Sens Environ 43:243-263

Pickup G, Bastin GN, Chewings VH (1994) Remote sensingbased condition assessment for non-equilibrium rangelands under large-scale commercial grazing. Ecol Appl 4:497-517

Pickup G, Bastin GN, Chewings VH (1998) Identifying trends in land degradation in non-equilibrium rangelands. J Appl Ecol 35:365-377

Pickup G, Bastin GN, Chewings VH (2000) Measuring rangeland vegetation with airborne videography in the bluenear infrared spectral region. Int $\mathrm{J}$ Remote Sens 21: $339-351$

Prince SD, Justice CO, Los SO (1990) Remote sensing of Sahelian environment. A review of the current status and future prospects. Commission of the European Communities, Brussels

Reeves CV (1972) Earthquakes in Ngamiland. Botswana Notes Records 4:257-261

Ringrose S, Matheson W, Tempest F, Boyle T (1990) An attempt to separate climatic and man-induced causes of range degradation in Botswana using Landsat MSS imagery. Geocarto Int 5:41-56

Ringrose S, Van der Post C, Matheson W (1996) The use of integrated remotely sensed and GIS data to determine causes of vegetation cover change in southern Botswana. Appl Geogr 16:225-242

Ringrose S, Van der Post C, Matheson W (1997) Use of image processing and GIS techniques to determine the extent and possible causes of land management/fenceline in- duced degradation problems in the Okavango area, northern Botswana. Int J Remote Sens 18:2337-2364

Rowlands IH (ed) (1998) Climate change cooperation in Southern Africa. UNEP, EARTHSCAN, London

Sandford S (1980) Keeping an eye on TGLP. National Institute of Development and Cultural Research, University of Botswana, Gaborone

Scholes RJ (1999) Will the terrestrial carbon sink saturate soon? Global Change Newsl 37:2-3

Scholes RJ, Parsons DAB (eds) (1997) The Kalahari transects: research on global change and sustainable development in Southern Africa. IGBP Report 42, Stockholm

Schott JR, Salvaggio C, Volchok WJ (1988) Radiometric scene normalisation using pseudoinvariant features. Remote Sens Environ 26:1-6

Sekhwela BM, Dube OP (1991) Desertification in the Ngamiland Communal First Development Area (CFDA). Working paper 55. National Institute of Development Research and Documentation (NIR), University of Botswana, Gaborone

Shaw P (1984) A historical note on the outflow of the Okavango Delta system. Botswana Notes Records 1:127-130

Shaw P (1985) The dessication of Lake Ngami: an historical perspective. Geogr J 151:318-326

Snowy Mountains Engineering Corporation (1987) Southern Okavango Integrated Water Development Phase 1. Final Report, Vol II. Department of Water Affairs, Ministry of Mineral Resources and Water Affairs, Gaborone

Tolsma DJ (1989) On the ecology of savanna ecosystems in south-eastern Botswana. PhD thesis, Centrale Huisdrukkerij Vrije Universiteit, Amsterdam

Tsimako B (1991) The Tribal Grazing Land Policy ranches performance to date. Ministry of Agriculture, Gaborone

Turner BL, Skole D, Sanderson S, Fischer LF, Leemans R (1995) Land-use and land-cover change Science/research plan. IGBP Report 35, HDO Report 7, Stockholm

van Vegten JA (1981) Man-made vegetation changes: an example from Botswana's savanna. National Institute of Development and Cultural Research. University of Botswana, Gabarone

Verlinden A (1997) Human settlements and wildlife distribution in the Southern African Kalahari of Botswana. Biol Conserv 82:129-136

Walker BH (1994) Landscape to regional-scale responses of terrestrial ecosystems to global change. Ambio XXIII(1): $67-73$

Ward D, Ngairorue BT, Kathena J, Samuel R, Ofran Y (1998) Land degradation is not a necessary outcome of communal pastoralism in arid Namibia. J Arid Environ 40:357-371

Ward KW (1978) Livestock marketing and supplementary feeding in times of drought. Drought Symposium, Botswana Society, Gaborone

Watson R, Zinyowera MC, Moss RH, Dokken DJ (eds) (1995) Climate change 1995. Impacts adaptation and mitigation of climate change: scientific-technical analyses. Contribution of Working Group II to the Second Assessment of the Intergovernmental Panel on Climate Change. Cambridge University Press, Cambridge

Westoby M, Walker B, Noy-Meir I (1989) Opportunistic management for rangelands not at equilibrium. J Range Manage 42:266-274

White R (1993) Livestock development and pastoral production on communal rangelands in Botswana. The Botswana Society, Gaborone

Wilson BH (1973) Some natural and man-made changes in the channels of the Okavango Delta. Botswana Notes Records 5:132-153 